\title{
Antioxidant and antibacterial activities of Ischaemum indicum leaves extracted using different solvents
}

\author{
Fithrotul Auwaliyah, Hamdan Dwi Rizqi, Adi Setyo Purnomo, Sri Fatmawati \\ Department of Chemistry, Faculty of Science, Institut Teknologi Sepuluh Nopember (ITS), Kampus ITS-Sukolilo, Jalan Arif Rahman Hakim, \\ Surabaya 60111, Indonesia \\ * Corresponding author: fatma@chem.its.ac.id
}

\section{Article history}

Received 23 February 2018

Revised 5 June 2018

Accepted 25 July 2018

Published Online 25 June 2019

\begin{abstract}
The aim of this study was to evaluate antioxidant and antibacterial activities of Ischaemum indicum leaves extracts based on different polarity solvents: water, methanol, ethyl acetate, dichloromethane, and $n$-hexane. The antioxidant activity was evaluated using ABTS and DPPH methods, while the antibacterial activity was determined by broth dilution method against Pseudomonas aeruginosa and Bacillus subtilis. The results showed that water and methanol extracts of $I$. indicum gave the highest antioxidant activity in ABTS assay with an $\mathrm{IC}_{50} 73.80$ and $46.32 \mu \mathrm{g} / \mathrm{mL}$, respectively. On the other hand, The $\mathrm{IC}_{50}$ on DPPH assay for water extracts was $117.51 \mu \mathrm{g} / \mathrm{mL}$, this value was higher than that of methanol extract with no inhibition. Methanol and water extracts showed the antibacterial activity against $B$. subtilis with inhibition of 48.62 and $45.11 \%$, whereas inhibition of $P$. aeruginosa were 31.95 and $30.31 \%$, respectively. This study denoted that $I$. indicum is a new potential candidate as antioxidant source.
\end{abstract}

Keywords: Ischaemum indicum, ABTS, DPPH, Antioxidant, Antibacterial.

\section{INTRODUCTION}

Traditional medicines have increasing demand in many countries, especially in developed countries where western medicinal practices are long been standard. One of sources of the traditional medicines is from plant. Plant serves the most important and efficient sources of natural medicine for a healthy life, which is neither harmful nor has any side effects, as well as it also contains a large number of nutrients. Medical plants as well as their purified components have revealed valuable therapeutic potentials. A variety of plant species has been reported to possess antioxidant and antimicrobial activities (Aqil et al., 2006). One of plants that have a fine antioxidant activity is Moringa olifera methanol extract with $\mathrm{IC}_{50}$ of $11.73 \mu \mathrm{g} / \mathrm{mL}$ in $\mathrm{DPPH}$ assay (Fitriana et al., 2016).

A great number of plants worlwide has been proved to present a strong antioxidant activity and a powerful scavenger activity against free radical (Chon et al., 2009). Free radicals are molecules or atoms that have at least an unpaired electron which usually increases the chemicals reactivity of the molecule. The sources of free radicals are from our body when it produces energy, under some circumtances including exposure to some environmental pollutants such as ultra violet radiations, smoke and pesticides (Bagchi, 1998). There is an increased evidence for the participation of free radicals in the aetiology of various diseases such as cancer, diabetes, cardiovascular diseases, aging (Beekman and Ames, 1998), inflammatory, atherosclerosis, neurodegenerative, HIV/AIDS and cataracts (Awah et al., 2010).

Antioxidant compounds can delay or inhibit the oxidation reaction of lipid or other biomolecules by inhibiting the initiation or propagation of oxidation chain reactions. Molecules called antioxidants can protect against free radical damages and their action permit to ensure a balance between production and destruction of free radicals, quenching them and thereby preventing further damage to cellular cell, thus consequently hindering various diseases (Kumar, 2012). A wide range of antioxidants has been proposed for the treatment of various human diseases (Hark L, 2006). Antioxidant is very important due to its ability to inhibit free radical in foods and in biological systems (Fauzia et al., 2016). In the food industry, antioxidants are used to prevent rancidity of foodstuffs. The synthetic antioxidants which are commonly used such as butylated hydroxyl toluena (BHT) and butylated hydroxyl anisole (BHA), are having potential of antioxidants. However, those synthetic antioxidants also have been found to brings side effects, for instance toxic and carcinogenic (Li et al., 2007). In other words, plants offer a safe and effective alternative to aforementioned issues.

Antioxidant activity is broadly used as a parameter to characterize different substances and food samples from natural product or synthesis with the ability of scavenging or neutralizing free radicals. This activity is associated to the presence of compounds with ability of protecting a biological system againts harmful oxidation (Pyrzynska, 2013). There are several methods used to evaluate the antioxidant activity of compounds from natural product or synthesis with varying results. Among the methods that used for identifying antioxidant activity are 2,2'- azino-bis (3-ethylbenzothiazoline-6-sulphonic acid) (ABTS) and 2,2- diphenyl -1-picrylhydrazyl (DPPH).

In other cases, many infectious diseases caused by bacteria have a large impact on public health (Khan et al., 2013). The appearance of antibiotics had reformed humanity's health condition and quality life. However, misuse and overuse of antibiotics had resulted in occurrence of bacterial resistance to commercially available antibiotics (Fankam et al., 2014). Therefore, one of new alternative therapeutic agents for inhibiting activity of bacteria is from natural origins, such as plants that 
are effective against antibiotic resistant bacteria, safe and cost-effective that have been searched constantly (Ivanova et al., 2013; Diastuti et al., 2014).

Antibacterial activity is a parameter to know a substance or compound that can inhibit or kill the bacterial cell growth. Antibacterial can control the growth and metabolism of harmful bacteria. The aims control of bacterial growth is to prevent the spread of disease and infection, as well as to prevent the decay and destruction of substance by bacteria (Arias et al., 2004). Antibacterial resistance has become a global problem that needs a solution to solve this. The strategies to improve the current situation include finding new potential sources of antibacterial with research of natural product or synthesis of antibacterial compound. Plants have great potential in producing new drugs of great benefit to human. Natural plants have been seen as a valuable source of medical agents with proven potential for treating infectious diseases with less side effects than synthetic product (Akuodor et al., 2011).

There are several methods used to evaluate the antibacterial activity of plant extracts with varying results. The one of methods that used for identifying antibacterial activity is broth dilution method. This method is applied to determine the lowest concentration of antibacterial to inhibit the visible growth of bacteria being investigated. Broth dilution method can decrease much labor and time, more sensitive than screening agar methods and most appropriate for a rapid quantitative determination of the antibacterial activity of extracts (Hassan et al., 2009).

Indonesia is one of developing countries that has many species of plants. Kadiman (2006) reported 30000 species of plants in Indonesia, in which 9606 species have been used as medicinal plants. One of the plants from Indonesian traditional medicines is family Poaceae (grass family). This family is commonly called Graminae, which is widely distributed in every continent except Greenland and Antartica. Grasses are common in areas of heavy rainfall, in deep shade of tropical forests, in full sun in deserts, from near the poles to the equator and from sea level to high altitudes (Kellogg, 2015). Graminae is the largest family of monocots, by having 620 genera and 10000 species throughout the world (Nasir et al., 1982). Some species of Poaceae have been exhibited with antioxidant and antibacterial activities such as Cynodon dactylon (Raj et al., 2013), Imperata cylindrica (Luis, 2015), Cyperus kyllingia (Pyne, 2011), and Echinochola colona (Ajaib et al., 2013). These reports indicated that most of species from Poaceae have potential as antioxidant and antibacterial sources.

Ischemum indicum in Indonesia is known as alang-alang which is traditionally used for the treatment of cold, fever, anti pyretic and as health supplement. This plant is one of the species of Poaceae, that widespread in tropical and semitropical regions in many countries and hypotesized to possess bioactivities potency for antioxidant and antibacterial activity. To date, antioxidant and antibacterial activities of I. indicum have not been reported yet. The aim of this study wasis to evaluate antioxidant and antibacterial activities of I. Indicum extracts from five different polarity solvents: water, methanol, ethyl acetate, dichloromethane and $n$-hexane. The antioxidant activity was assessed by using ABTS and DPPH methods while antibacterial activity was measured by using broth dilution method.

\section{EXPERIMENTAL}

\section{Materials}

The chemicals that have been used in the present study such as 2,2diphenyl -1-picrylhydrazyl (DPPH) was purchased from Tokyo Chemical Industry (TCI), 2,2'-azino-bis (3-ethylbenzothiazoline-6sulphonic acid) (ABTS) was purchased from Sigma Aldrich, $\mathrm{K}_{2} \mathrm{~S}_{2} \mathrm{O}_{8}$ (potassium peroxydisulfate), methanol, ethyl acetate, dichloro methane, $n$-hexane, dimethyl sulfoxide (DMSO), Nutrient Broth (NB) were purchased from Merck. Gallic acid and Trolox (6-hydroxy- 2,5,7,8tetramethylchroman- 2- carboxylic acid) were purchased from Wako Pure Chemical Industries (Osaka, Japan). The bacterial strains used for the study were Bacillus subtilis (Gram positive) and Pseudomonas aeruginosa (Gram negative). Bacteria Strains were obtained from the Collection of Microorganism Chemistry Laboratory, Department of Chemistry, Institut Teknologi Sepuluh Nopember.

\section{Preparation of $I$. Indicum leaves extract}

I. indicum leaves were collected from paddy field in Surabaya, Indonesia. The samples were washed throughly, chopped into small pieces and shade dried. The samples were pulverized in an electric blender. The powdered samples were used for futher extraction ((Raj et al., 2013). Samples were extracted using 5 different solvents (water, methanol, ethyl acetate, dichloromethane, and $n$-hexane) in an erlenmeyer flask $(500 \mathrm{~mL})$ on a shaker with agitation fixed on $170 \mathrm{rpm}$, at room temperature for $24 \mathrm{~h}$ with solid-solvent ratio (1:20). The extracts were filtered through filter paper. Then, all filtrates from extracts were evaporated by using a rotary evaporator and all the crude extracts were stored in air tight container prior to usage for assay (Cujic, 2015).

\section{Antioxidant activity assay}

ABTS and DPPH assays were performed to determine the free radical scavenging potential of $I$. indicum leaves extracts.

\section{ABTS radical scavenging assay}

The capability of I. indicum leaves extracts to scavenge 2,2'-azinobis (3-ethylbenzothiazoline-6-sulphonic acid) (ABTS) radical was performed with slight modification in method based on study of Re et al., (1999). The ABTS solution was made from $5 \mathrm{~mL}$ of $0.7 \mathrm{mM}$ ABTS and reacted with a solution of potassium peroxydisulfate $\left(\mathrm{K}_{2} \mathrm{~S}_{2} \mathrm{O}_{8}\right)(88$ $\mu \mathrm{L}$ of $140 \mathrm{mM}$ ). Then the solution was incubated in darkness for 12-16 hours at room temperature to form ABTS radical cation $\left(\mathrm{ABTS}^{-+}\right)$. The reagent was diluted with ethanol $99.5 \%$ to give an absorbance $0.7 \pm$ 0.02 at wavelength $734 \mathrm{~nm}$. The test solution was obtained from the dissolution of the extract in DMSO $(10 \mathrm{mg} / \mathrm{mL})$. The assay solution was taken in $10 \mu \mathrm{L}$ and added with $1 \mathrm{~mL} \mathrm{ABTS}^{-+}$radical solution, and then incubated for 4 minutes at room temperature. The solution was measured its absorbance with UV-Vis spectrophotometer at wavelength $734 \mathrm{~nm}$. Trolox was used as positive control. For blank, 10 $\mu \mathrm{L}$ DMSO was mixed with $1 \mathrm{~mL}$ ABTS solution and registered at the same absorbancies.

The free radical scavenging activities were expressed in $\mu \mathrm{g} / \mathrm{mL}$. The analysis in each extracts was done in triplicate. The capacity of antioxidant from extract to scavenge the ABTS radical was calculated by using the following formula:

$$
\begin{aligned}
& \text { ABTS radical scavenging activity }(\%)= \\
& {[(\text { Absblankl-Abs } \text { sample }) /(\text { Absblank })] \times 100}
\end{aligned}
$$

\section{Where:}

Absblank $=$ the absorbance of ABTS radical $(=0.700 \pm 0.02)$

$\mathrm{Abs}_{\text {sample }}=$ the absorbance of sample + ABTS radical.

The extract which has a fine ABTS radical scavenging activity (\%), was measured its $\mathrm{IC}_{50}$ value $(\mu \mathrm{g} / \mathrm{mL})$. The $\mathrm{IC}_{50}$ value was calculated from the linier regression of plots of concentration of the test sample against the mean percentage of the antioxidant activity obtained from triplicate assays. The $\mathrm{IC}_{50}$ value was referred to the effective extracts concentration to scavenge the $\mathrm{ABTS}^{-+}$radicals by $50 \%$.

\section{DPPH radical scavenging assay}

The capability of I. indicum leaves extracts to scavenge 2,2diphenyl -1-picrylhydrazyl (DPPH) radical was determined according to the method (Zhou et al., 2011) with some modification. The test solution was obtained from the dissolution of the extract in methanol $(10 \mathrm{mg} / \mathrm{mL})$. The reaction mixture was consisted of $1 \mathrm{~mL} \mathrm{DPPH}$ solution $6 \times 10^{-5} \mathrm{M}$ and mixed with $33 \mu \mathrm{L}$ of extract solution. Then, it was incubated for 20 minutes at room temperature $\left(37^{\circ} \mathrm{C}\right)$. Next, the solution absorbance was measured with UV-Vis spectrophotometer at $517 \mathrm{~nm}$. Blank sample with $33 \mu \mathrm{L}$ of methanol in DPPH solution was prepared and measured at same wavelength. Gallic acid was used as positive control.

The DPPH radical scavenging activities (\%) was calculated by the following equation: 
DPPH radical scavenging activity $(\%)=$

$[($ Absblankl-Abs sample $) /($ Absblank $)]$ x 100

Where:

Absblank $=$ the absorbance of DPPH radical

$\mathrm{Abs}_{\text {sample }}=$ the absorbance of sample + DPPH radical.

The extract with high DPPH radical scavenging activity (\%), was measured its $\mathrm{IC}_{50}$ value $(\mu \mathrm{g} / \mathrm{mL})$. The IC 50 value was calculated from the linier regression of plots of concentration of the test sample against the mean percentage of the antioxidant activity obtained from triplicate assays. The $\mathrm{IC}_{50}$ value was referred to the effective extracts concentration to scavenge the DPPH radicals by $50 \%$.

\section{Antibacterial activity assay}

\section{Preparation of the bacterial suspension}

A total of $0.8 \mathrm{~g}$ nutrien broth was dissolved in $100 \mathrm{~mL}$ aquades. The solution was then autoclaved at $121{ }^{\circ} \mathrm{C}$ for 15 minutes. Then each of bacteria ( $B$. subtilis and $P$. aeruginosa) was put into nutrient broth solution in erlenmeyer $25 \mathrm{~mL}$. Next, each bacteria was incubated at $37^{\circ} \mathrm{C}$ using shaker incubator (B. subtilis for 20 hours while $P$. aeruginosa for 21 hours) (Jiang, 2011).

\section{Measurement of antibacterial activity by broth dilution method}

The antibacterial activity of $I$. indicum leaves extracts was performed against Gram positive bacteria: B. subtilis and Gram negative bacteria: $P$. aeruginosa by using broth dilution method (Jiang, 2011). Each extracts was dissolved in DMSO $(10 \mathrm{mg} / \mathrm{mL})$. A $500 \mu \mathrm{L}$ mixture was made from $445 \mu \mathrm{L}$ nutrien broth (NB) medium, each of bacteria suspention $10^{4} \mathrm{CFU} / \mathrm{mL}(50 \mu \mathrm{L})$ and $5 \mu \mathrm{L}$ extract solution. The assay solution was taken $150 \mu \mathrm{L}$ and inserted to 96 microwell plate and replicated three times for each sample, then incubated for 18 hours at $37^{\circ} \mathrm{C}$ using shaker incubator. Further, the cell density was measured at $\mathrm{OD}_{630}$ by using 96 -microwell plate reader. Ampicilin was used as the positive control while DMSO was used as the negative control.

\section{RESULTS AND DISCUSSION}

\section{Yield extraction}

The crude extracts of $I$. indicum were obtained by maceration method with five different solvents based on polarity (water, methanol, ethyl acetate, dichloromethane, and $n$-hexane). The percentages of extraction yield are shown in Table 1.

Table 1 Extraction yield of I. Indicum.

\begin{tabular}{ccc}
\hline Extracts & $\begin{array}{c}\text { Extraction yield } \\
(\mathbf{g})\end{array}$ & Yield (\%) \\
\hline Water & 2.48 & 16.50 \\
Methanol & 0.53 & 3.53 \\
Ethyl acetate & 0.29 & 1.90 \\
Dichloro methane & 0.26 & 1.70 \\
$n$-hexane & 0.13 & 0.87 \\
\hline
\end{tabular}

The highest yield was showed in water extract, about $2.48 \mathrm{~g}$ from $15 \mathrm{~g}$ dried sample, while the lowest one was in $n$-hexane extract, about $0.13 \mathrm{~g}$ from $15 \mathrm{~g}$ dried sample. Polar solvent showed greater yield than apotric and nonpolar solvent. Polar solvent allows to solvate low molecular weight organic compounds possessing proton table functional groups (e.g. $\mathrm{COOH}, \mathrm{OH})$ (Nguyen et al., 2015). It indicated that polar compounds in I. indicum are higher than that of non polar compounds.

\section{Antioxidant activity}

The radical scavenging activity of $I$. indicum leaves extracts was tested using the ABTS and DPPH assays. The principle of ABTS assay is the radical cation decolorization through the transfer of electrons that neutralize free radicals which are marked with a dark blue color change to yellow light (Zurowska, 2012). ABTS is soluble in both aqueous and organic solvents. This assay can be used in multiple media to determine both hydrophilic and lipophilic antioxidant capacities of extracts. ABTS reacts rapidly with antioxidant. This assay can be used to determine effects of $\mathrm{pH}$ on antioxidant mecanisms, leading to the ABTS wide $\mathrm{pH}$ range ability (Prior et al., 2005).

Antioxidant activities of five extracts I. Indicum based on ABTS assay at aconcentration of $99.01 \mu \mathrm{g} / \mathrm{mL}$ are presented in Fig. 1. The percentages of antioxidant activity of various extracts; water, methanol, ethyl acetate, dichloromethane, and hexane were 66.62, 82.05, 40.95, 39.55 , and $16.13 \%$, respectively. Trolox as a positive control has antioxidant activity of $91.3 \%$. The methanol and water extract have the highest activity among the other leaves extracts, due to these extracts may contain many phenolic compounds that contribute to antioxidant activity.

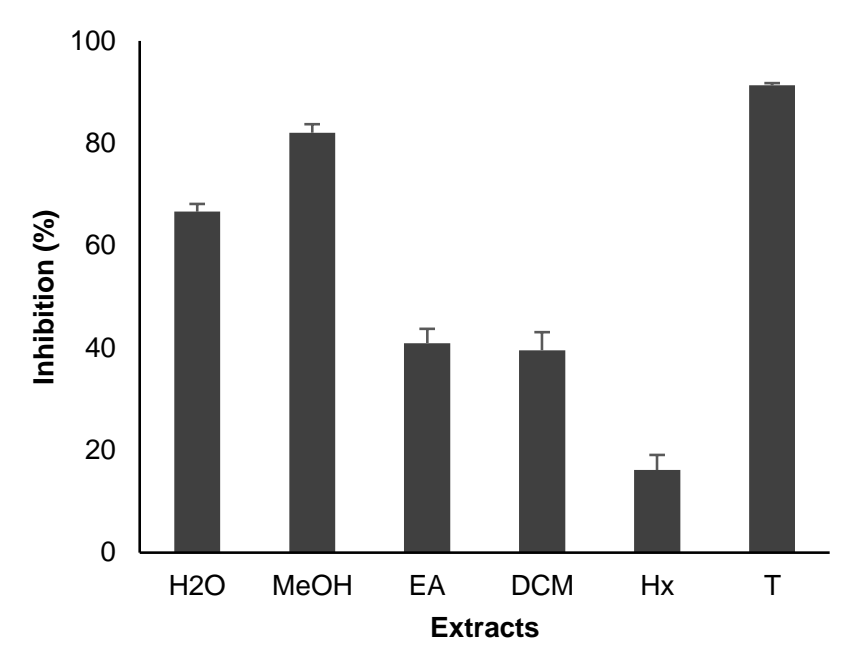

Fig. 1 ABTS radical scavenging ability of $I$. indicum leaves extracts at a concentration of $99,01 \mu \mathrm{g} / \mathrm{mL}, \mathrm{H}_{2} \mathrm{O}$ water extract; $\mathrm{MeOH}$, methanol extract; EA, ethyl acetate extract; DCM, dichloromethane extract; $\mathrm{Hx}$, Hexane extract and T, trolox (positive control). Each column represents the mean $\pm S D, n=3$.

The methanol and water extracts showed higher activity than that of the other extracts. Determination of $\mathrm{IC}_{50}$ value for water and methanol extracts was performed to show the doses of the extract that could reduce the intensity of $50 \%$ free radical absorption.

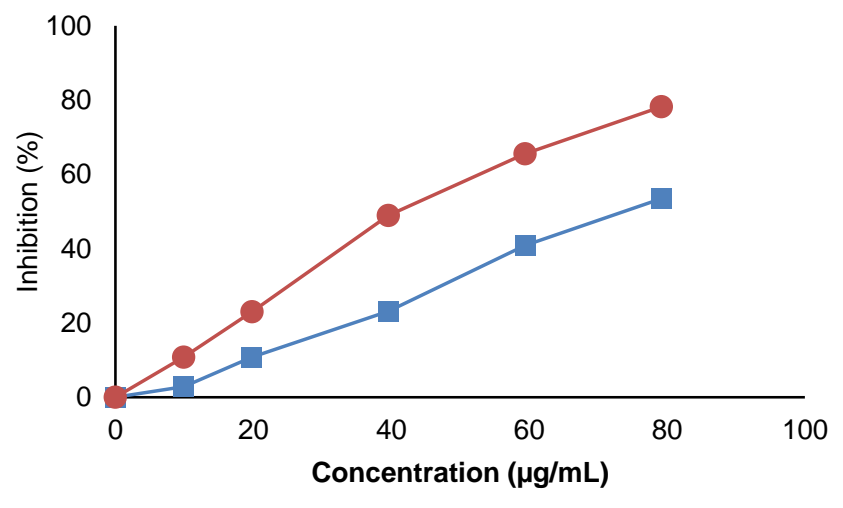

$\longrightarrow$ Water Extract $\longrightarrow$ Methanol Extract

Fig. 2 ABTS radical scavenging ability of $I$. indicum methanol and water extracts.

Based on the result of interpolation of Fig. 2, the $\mathrm{IC}_{50}$ values of $I$. Indicum methanol and water extracts were 46.32 and $73.80 \mu \mathrm{g} / \mathrm{mL}$, respectively. The study reported that the methanol and water extracts of I. indicum exhibited good ABTS scavenging activities. The results of the present investigation explains that the methanol and water extracts of $I$. indicum may contain enormous amount of hydrogen donor 
molecules which may reduce the production of radicals due to the fact that methanol and water extracts of I. indicum are polar compound. Phenolic compound is one class of polar compounds that acting as antioxidants which contains one or more hydrogen donors (Hidayati, 2017). The antioxidative activity of phenolic compounds plays an important role in absorption and neutralization of free radicals. Phenolic compounds are classified as simple phenols, single aromatic ring with one hydroxyl group and polyphenol with two or more subunits such as flavonoids, or three or more phenol subunits, called tannin (Sultana et al., 2007).

Antioxidant activiy of $I$. indicum leaves extracts was also performed by using the DPPH method. A rapid, simple, inexpensive method for measuring antioxidant activity has been developed, which it is widely used to test the ability of compounds that indicated to be antioxidant to act as free radical scavengers or hydrogen donors. 2,2diphenyl-1-picrylhydrazyl (DPPH) is a method of measuring the antioxidant activity which is widely used to test the activity of natural compounds in food and quantify antioxidants in new drugs and complex biological systems (Shalaby et al., 2012).

DPPH is a stable free radical, nitrogen-centred free radical that readily accepts an electron or hydrogen radical to become a stable diamagnetic molecule. The radical DPPH reacts with suitable reducing agents, as a result of which the electrons become pair to form hydrazine. The solution of DPPH therefore loses colour stoichiometrically, depending on the number of electron taken up. Antioxidant compound is capable in contributing its electron or hydrogen atoms, converting the colour of radical DPPH (which is purple) into the non-radical DPPH (which is yellow) (Nithya, 2014). DPPH assay is one of simple and rapid test. This assay needs UV-Vis spectrophotometry to determine the absorbance of compound (Prior et al., 2005).

The results of antioxidant activity of five extracts I. Indicum in DPPH assay at aconcentration of $319.46 \mu \mathrm{g} / \mathrm{mL}$ are presented in Fig. 3 . The percentages of antioxidant activity of various extracts; water, methanol, ethyl acetate, dichloromethane, and hexane were 74.45 , $43.51,18.71,16.51$, and $8.63 \%$, respectively. Gallic acid as a positive control has antioxidant activity of $97.79 \%$. The water extract hads the highest activity among the other leaves extracts, due to these extracts may contain many phenolic compounds that contribute to antioxidant activity.

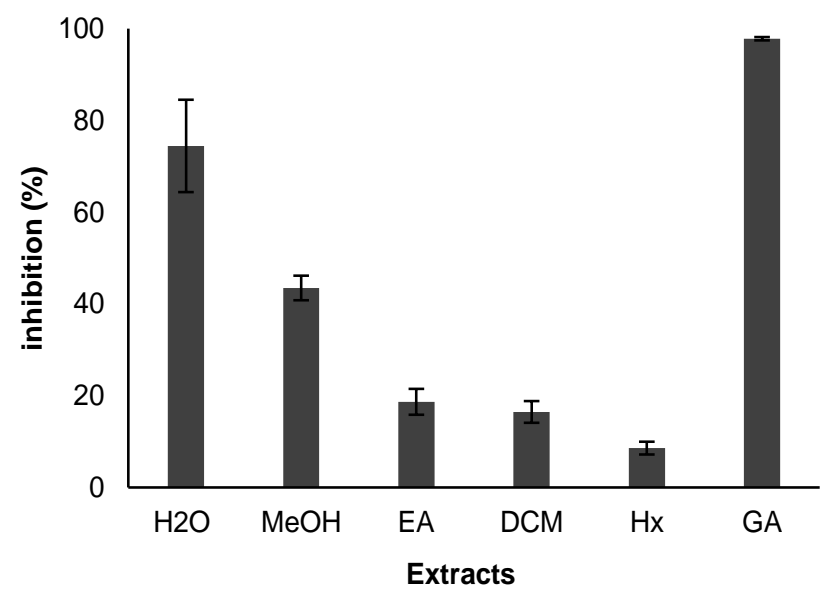

Fig. 3 DPPH radical scavenging ability of $I$. indicum leaves extracts at a concentration of $319.46 \mu \mathrm{g} / \mathrm{mL}, \mathrm{H}_{2} \mathrm{O}$ water extract; $\mathrm{MeOH}$, methanol extract; EA, ethyl acetate extract; DCM, dichloromethane extract; $\mathrm{Hx}$, Hexane extract and GA, gallic acid (positive control). Each column represents the mean $\pm S D, n=3$.

The extract which showed the highest activity needs to clarify its $\mathrm{IC}_{50}$ value. In this assay, I. Indicum water extract has the highest activity to scavenge DPPH radical than the other extracts. Determination of $\mathrm{IC}_{50}$ value for the highest antioxidant activity extracts was done to perform the doses of extract that could reduce intensity of $50 \%$ free radical absorption.

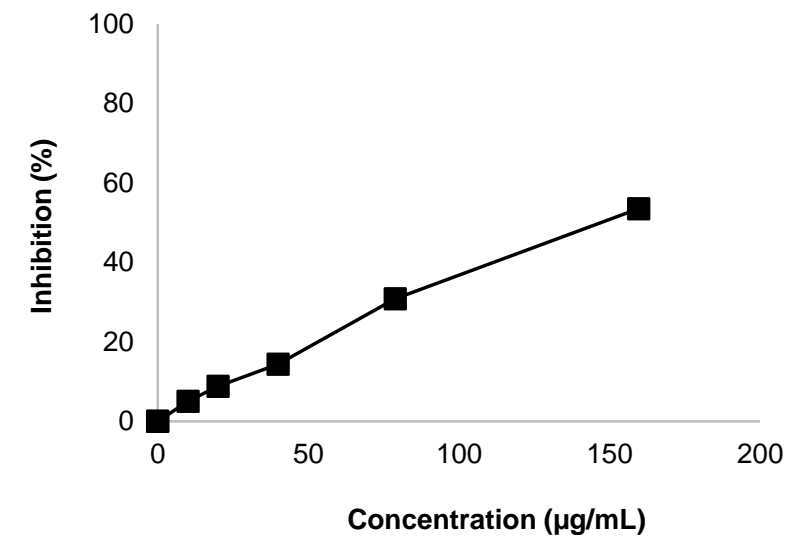

Fig. $4 \mathrm{DPPH}$ radical scavenging ability of $I$. indicum water extract.

Based on the result of interpolation of concentration and inhibition, the $\mathrm{IC}_{50}$ value of $I$. Indicum water extract was $117.51 \mu \mathrm{g} / \mathrm{mL}$. Gallic acid as positive control has higher activity than that of water extract with $\mathrm{IC}_{50}$ value of $2.12 \mu \mathrm{g} / \mathrm{mL}$. Gallic acid consists of an aromatic ring with substitution of three hydroxyl groups and one carboxylate group. The existence of these groups has an important role to determine the efficiency of compound in free radical inhibition.

Based on both antioxidant assays, it showed that methanol extract was the most potential extract to scavenges free radical ABTS and water extract in scavenges free radical DPPH. This result indicated that polar extract has strong antioxidant activity. The same result also shown by Emam et al. (2007), in which the antioxidant activity of leaves crude extracts of Juniperus excels has higher activity in polar solvent.

\section{Antibacterial activity}

The antibacterial activity of I. indicum leaves extracts was assessed by using broth dilution method. The sensitivity of tested Gram positive bacteria; B. Subtilis and Gram negative bacteria; P. aeruginosa to different polarity solvents (water, methanol, ethyl acetate, dichlorometane, $n$-hexane) was variable. The results showed that methanol and water extracts gave the highest antibacterial activity against $B$. subtilis and $P$. aeruginosa than other extracts. These results indicated that polar extract gives activity against both bacteria. The antibacterial activities of $I$. indicum leaves extracts are shown in Table 2 .

Table 2 Antibacterial activity of $I$. indicum leaves extracts against $B$. Subtilis and P.aeruginosa.

\begin{tabular}{|c|c|c|}
\hline \multirow{2}{*}{ Extracts } & \multicolumn{2}{|c|}{ Inhibition (\%) } \\
\cline { 2 - 3 } & B. subtilis & P. aeruginosa \\
\hline Water & $45.11 \pm 0.012$ & $30.31 \pm 0.005$ \\
\hline Methanol & $48.62 \pm 0,005$ & $31.95 \pm 0.011$ \\
\hline Ethyl acetate & 0 & 0 \\
\hline Dichlorometane & 0 & 0 \\
\hline n-Hexane & $0,00 \pm 0,010$ & 0 \\
\hline $\begin{array}{c}\text { Ampicilin } \\
\text { (Positive control) }\end{array}$ & $101.13 \pm 0,002$ & $99.49 \pm 0.052$ \\
\hline
\end{tabular}

Table 2 shows that antibacterial activity exhibited higher inhibition on the Gram-positive bacteria (B. subtilis) than that of the Gramnegative bacteria ( $P$. aeruginosa). The reason for the difference in sensitivity between Gram-positive and Gram-negative bacteria may be described by the differences in morphological constitutions between these microorganisms. Gram-negative bacteria have an outer phospholipidic membrane that carries the structural lipopolysaccharide components. This makes the cell wall impermeable to antimicrobial chemical substances. The Gram-positive bacteria on the other hand are more susceptible in having only an outer peptidoglycan 
layer which is not an effective permeability barrier. Therefore, the cell walls of Gram-negative organisms, which are more complex than that of the Gram-positive ones. They act as a diffusional barrier, making them less susceptible to the antimicrobial agents than Gram-positive bacteria (Nostro et al., 2000).

\section{CONCLUSION}

The highest antioxidant activities were shown by methanol and water extracts of I. Indicum. Antibacterial activity of these extracts showed medium inhibition against $B$. subtilis and $P$. aeruginosa. The present study indicated that $I$. indicum could be used as new potential source for antioxidant and antibacterial.

\section{ACKNOWLEDGEMENT}

This work was supported by a grant from research project for International Research Collaboration and Scientific Publication from the Directorate of Research and Community Service, Directorate General of Strengthening Research and Development, Ministry of Research, Technology and Higher Education, Indonesia. The financial support for Fithrotul A. from Indonesia Endowment Fund for Education was also acknowledged.

\section{REFERENCES}

Ajaib, M., Khalid, M. K., Shahnaz, P., Shazia, S. Antimicrobial and antioxidant activities of echinochola colona (Linn.) link and sporobolus coroamdelianus (Retz) Kunth. Journal of the Chemical Society of Pakistan., vol. 35, no. 3, pp. 961-966, 2013.

Akuodor, G. C., Essien, A. D., Ibrahim, J. A., Bassey, A., Akpan, J. L., Ikoro, N. C., Onyewenjo, S. C. Phytochemical and antimicrobial properties of the methanolic extract of Bombax buanopozense leaf and root. Asian Journal of Medical Sciences, vol. 2, pp. 190-194, 2011.

Aqil, F. I., Ahmed, I., Mehmood, Z. Antioxidant and free radical scavenging properties of twelve traditionally used Indian medical plants. Turkish Journal of Biology, vol. 30, pp. 177-183, 2006.

Arias, M. E., Gomez, J. D., Cudmani, N. M., Vattuone, M. A., Isla, M. I Antibacterial activity of ethanolic and aqueous extracts of Acacia aroma Gill Ex Hook et Arn. Life Sciences, vol. 75, pp. 191-202, 2004.

Awah, F. M., Uzoegwu, P. N., Oyugi, J. O., Rutherford, J., Ifeonu, P., Yao, X., Fowke, K. R., Eze, M. O. Free radical scavenging activity and immunomodulatory effect of Stachytarpheta angustifolia leaf exract. Food Chemistry, vol. 119, pp. 1409-1416, 2010.

Bagchi, K., Puri, S. Free radicals and antioxidants in health and diseases. Eastern Mediterranean Health Journal, vol. 4, pp. 350-360, 1998.

Beckman, K. B., Ames, B. N. The free radical theory of aging matures. Physiological Reviews, vol. 78, pp. 547-581, 1998.

Chon, S. U., Heo, B. G., Park, Y. S., Kim, D. K., Gorinstein, S. Total phenolic level, antioxidant activities and cytotoxicity of young sprouts of some traditional Korean salad plants, Plant Foods for Human Nutrition, vol. 62 , pp. 167-179, 2009.

Cujic, N., Savikin, K., Jankovic, T., Pljevljakusic, D., Zdunic, G., Ibric, S. Optimization of polyphenols extraction from dried chokeberry using maceration as traditional technique. Food Chemistry, vol. 194, pp. 135-142, 2016.

Diastuti, H., Syah, Y. M., Juliawaty, L. D., Singgih, M. Antibacterial Curcuma xanthorrhiza extract and fraction. Journal of Mathematical and Fundamental Sciences, vol. 46, no. 3, pp 224, 2014.

Emam, S. A., Asilii, J., Mohagheghi, Z., Hassanzadeh, M. K. Antioxidan activity of leaves and fruits of Iranian conifers. RSC Advances, vol. 4, no. 3, pp. 313-319, 2007.

Fankam, A. G., Kuiate, J. R., Kuete, V. Antibacterial activities of Belschmiedia obscura and six other Cameroonian medical plants against multi-drug resistant Gram-negative phenotypes. BMC Complementary and Alternative Medicine, vol. 14, pp. 241, 2014.

Fauzia, D. N., Fatmawati, S., Ersam, T. New prenylated stilbenes and antioxidant activities of Cajanus cajan (L.) Millsp. (Pigeon pea). Indonesian Journal of Chemistry, vol. 16, no.2, pp. 151-155. 2016

Fitriana, W. D., Ersam, T., Shimizu, K., Fatmawati, S. Antioxidant activities of moringa oliefera extracts. Indonesian Journal of Chemistry, vol. 16, no.3, pp. 297-301. 2016.

Hark, L., Deen, D. Nutrion for Life. London: Dorling Kindersley Publishers, pp. 213, 2006.
Hassan, A., Rahman, S., Deeba, F., Mahmud, S. Antimicrobial activity of some plant extracts having hepatoprotective effects. Journal of Medicinal Plants Research, vol. 3, no. 1, pp. 20-23, 2009.

Hidayati, M. D., Ersam, T., Shimizu, K.., Fatmawati, S. Antioxidant activity of Syzygium polynthum extracts. Indonesian Journal of Chemistry, vol. 17, no.1, pp. 49-53. 2017.

Ivanova, E., Atanasova, N., Kungulovski, D. Antimicrobial activities of laboratory produced essential oil solutions against five selecte fungal strains. Journal of Nature and Science, vol. 124, pp 171, 2013.

Jiang, L. Comparison of disk diffusion, agar dilution, and broth microdilution for antimicrobial susceptibility testing of five chitosans. Thesis, Fujian Agricultural and forestry University, China, 2011.

Kadiman, K. Buku Putih Penelitian, Pengembangan dan Penerapan Iptek Bidang Kesehatan dan Obat. Kementrian Negara Riset dan Teknologi Republik Indonesia, Jakarta, 2006.

Kellogg., Elizabeth, A. The Families and Genera of Vascular Palnt, Volume XIII :Flowering Plans Monocots Poaceae. Switzerland: Springer International Publishing, vol. 87-90, 2015.

Khan, U. A., Rahman, H., Niaz, Z., Qasim, M., Khan, J., Tayyaba. Antibacterial activity of some medical plants against selected human pathogenic bacteria. European Journal of Microbiology and Immunology, vol. 3, pp. 272, 2013.

Kumar, R. S., Rajkapoor, B., Perumal, P. Antioxidant activities of Indigofera cassioides Rottl. Ex. DC. using various in vitro assay models. Asian Pacific Journal of Tropical Biomedicine, pp. 256-261, 2012.

Li, H. B., Cheng, K., Wong, C., Fan, K., Chen, F., Jiang, Y. Evaluation of antioxidant capacity and total phenolic content of different fractions of selected microalgae. Food Chemistry, vol. 102, pp. 771-776, 2007.

Luis, K. M. Isolation and partial characterization of the antibacterial compounents of Cogon (Imperata cylindrical) Roots. Thesis. Mapua Institute of Technology, pp. 19-27, 2015.

Nasir, A., Ali, S. I. Flora of Pakistan. Poaceae, vol. 143, no. 2, pp. 142-196, 1982.

Nguyen, V. T., Bowyer, M. C., Vuong, Q. V., Altena, L. A. V., Scarlet, J. C. H. Phytochemicals and antioxidant capacity of Xao tam phan (Paramignya trimera) rot as affected by various solvents and extractions methods. Industrial Crops and Products, vol. 67, pp. 192-200, 2015.

Nithya, P., Madhavi, C. Antioxidant activity of 3-arylidene-4-piperidones in the 1,1-diphenyl-2-picrylhydrazyl scavenging assay. Journal of Taibah University for Science, vol. 11, pp. 40-45, 2017.

Nostro, A., Germano, M. P., D’Angelo, V., Marino, A., Cannatelli, M. A. N., Extraction methods and bioautography for evaluation of medicinal plant antimicrobial activity. Letters in Applied Microbiology, vol. 30, pp. 379384, 2000.

Pyne, S.G., Liawruangrath, S., Garson, M., Khamsan, S., "Antimalarial, Anticancer, Antimicrobial activities and chemical constituents of essential oil from the aerial parts of Cyperus kyllingia Endl,' M Garson. Rec. Natural Prod, vol. 5, no. 4, pp. 324-327, 2011.

Pyrzynska, K., Pekal, A. Aplication of free radical diphenylpicrylhydrazyl (DPPH) to estimate the antioxidant capacity of food samples. Anal Methods, vol. 5, pp. 4288-95, 2013.

Prior, R. L., Wu, X., Schaich, K. Standardized methods for the determination of antioxidant capacity and phenolics in foods and dietery supplements. Journal of Agricultural and Food Chemistry. vol. 53, no. 10, pp. 4290-4302, 2005.

Raj, S., Berthomier, M., Babu, M. A., Karthlkeyan, S., Sivakumar, A. Gothandam, K. M. Antioxidant, antibacerial and anti-proliferative activity and phytochemical analysis of selected medical plants from Dasapushpam of Kerala. International Journal of Pharmaceutical Sciences Review and Research, vol. 23, no. 1, pp. 172-179, 2013.

Re, R., Pellegrini, N., Proteggente, A., Pannala, A., Yang, M., Rice-Evans, C. Antioxidant activity applying an improved ABTS radical cation decolorization assay. Free Radical Biology and Medicine, vol. 26, no. 9-10, pp. 1231-1237, 1999.

Shalaby, E. A., Shanab, S. M. M.Comparison of DPPH and ABTS assays for determining antioxidant potential of water and methanol extracts of Spirulina platensis. Indian Journal of Geo-Marine Sciences, Vol. 42, no. 25. pp 556-564, 2012.

Sultana, B., Anwar, F., Przybylski, R. Antioxidant activity of phenolics components present in barks of Azadirachta indica, Terminalia arjuna, Acacia nilotica, and Eugenia jambolana Lam. Trees. Food Chemistry, vol. 104, no. 3, pp. 1106-1114, 2007.

Zhou, H. C., Lin, Y. M., Wei, S. D., Tam, N. F. Y. Structural diversity and antioxidant activity of condensed tannins fractionated from mangosteen pericarp. Food Chemistry, vol. 129, no. 4, pp. 1710-1720, 2011.

Zurowska, D. M., Wenta, W. A comparison of ABTS and DPPH methods for assessing the total antioxidant capacity of human milk. Journal Food Sciences and Nutrition Acta Scientiarum Polonorum, vol. 11, no. 1, pp. 8389, 2012. 